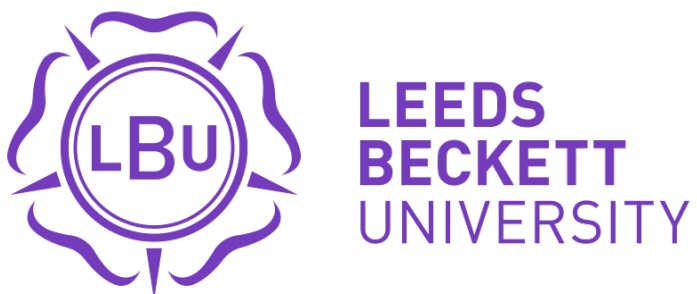

Citation:

Nasir, M-A and Leung, M (2020) US Trade Deficit, a Reality Check : New Evidence Incorporating Asymmetric and Nonlinear Effects of Exchange Rate Dynamics. The World Economy. ISSN 0309-1961 DOI: https://doi.org/10.1111/twec.12986

Link to Leeds Beckett Repository record:

https://eprints.leedsbeckett.ac.uk/id/eprint/6778/

Document Version:

Article (Published Version)

Creative Commons: Attribution 4.0

The aim of the Leeds Beckett Repository is to provide open access to our research, as required by funder policies and permitted by publishers and copyright law.

The Leeds Beckett repository holds a wide range of publications, each of which has been checked for copyright and the relevant embargo period has been applied by the Research Services team.

We operate on a standard take-down policy. If you are the author or publisher of an output and you would like it removed from the repository, please contact us and we will investigate on a case-by-case basis.

Each thesis in the repository has been cleared where necessary by the author for third party copyright. If you would like a thesis to be removed from the repository or believe there is an issue with copyright, please contact us on openaccess@leedsbeckett.ac.uk and we will investigate on a case-by-case basis. 


\title{
US trade deficit, a reality check: New evidence incorporating asymmetric and non-linear effects of exchange rate dynamics
}

\section{Muhammad Ali Nasir (D) | Mary Leung}

Economics, Analytics and International Business Subject Group, Leeds Business School, Leeds Beckett University, Leeds, UK

\author{
K E Y W O R D S \\ asymmetric J-curve, competitive devaluation, fiscal deficit, global imbalances, non-linear autoregressive distributed lag, price \\ stability, productivity, savings, trade war
}

\section{1 | INTRODUCTION}

The "global imbalances", a term often synonymously used for "current account imbalances", are central to the policy debates on the global political and economic forums (Borio, 2016). In this regard, the dynamics of the world's largest economy of the US with its gigantic trade volume has significant economic and political implications for the rest of the world. The US trade imbalance with its major trade partners has been a long-standing issue, particularly since the Global Financial Crisis (GFC) 2008-09. Though the downturn of the economy in aftermath of the GFC accompanied some improvements in the US trade balance, further elimination of trade deficit has not been witnessed since then, and in fact, there has been deterioration. A prima facie manifestation of US trade balance dynamics is depicted in Figure 1, which shows persistent and widening deficit since the early 1990s. This has caused a heated debate and, most recently, a trade war.

Since 2002, the US has experienced twin deficits, i.e., a growing budget deficit along with growing trade deficit. A United Nation's report proposed to tackle US massive trade deficit in a cautious process, which shall involve a reduction in domestic demand and increase in demand from its trading partners (see Hong, 2001). In this context, there is also a misperception that the rise of exports from emerging economies shall be blamed for the widening US deficit in recent years. Therefore, an aggressive approach to solve the trade deficit has been adopted by the new administration. For example, tariffs have been imposed on steel and alumina imported from Canada, Mexico and the European Union and a $25 \%$ tariff on \$ 200 billion worth of imports from China. The countries running large trade surpluses, particularly Japan, China and Germany, have been accused of competitive devaluation; however, similar to the US these countries had been focused on the provision of liquidity to the 
real economy in the post-GFC era, which might have led to some depreciation as a by-product of monetary policy actions (Briscoe, 2015; Hoffmann, 2013). Yet, post-Global Financial Crisis, there has been the politicisation of issues around global imbalances, particularly competitive devaluation and unfair trade distortions (Nasir \& Jackson, 2019; Variar, 2011). On this aspect, Čerović, Pepić, Petrović, \& Čerović (2014) argued that the crisis has reignited and fuelled the debate between liberalism versus protectionism and the protectionist measures have been taken to protect national interests. Shelburne (2010) echoed these concerns and argued that these measures have a beggar-thy-neighbour component. The recent act of putting China, Japan and Germany on the potential exchange rate manipulator observation list by the US and stance by the current administrations reinvigorated the debate on the competitive devaluation ${ }^{1}$ and unfair practices by the US trade partners. This debate and trade tensions between the US, China and other countries raise questions whether the US trade deficit can be attributed to the exchange rate dynamics? and whether there are also other factors that might be the cause of huge US trade deficit?

Economists have generally agreed that the exchange rates have potential implications for the external balance of an open economy (Bahmani-Oskooee \& Baek, 2016; Bahmani-Oskooee, Bose, \& Zhang, 2019; Bahmani-Oskooee \& Kutan, 2009; Bahmani-Oskooee \& Shah, 2017; Lee \& Chinn, 2006; Narayan, 2006). However, with reference to the US, some scholars, for instance, Eichengreen (2017), Fratzscher (2017), Lee, McKibbin, and Park (2006), Reinhart (2017) and Sachs (2017), suggested that it is an imbalance in the investment and saving than the issue of exchange rate manipulation or competitive devaluations, while with reference to some scholars, the trade disequilibria are associated with the financial liberalisation, which began in the 1980s (see, e.g., Caballero, Fahri, \& Gourinchas, 2008; Chakraborty and Dekle, 2009; Dooley, Folkerts-Landau, \& Garber, 2003). Steiner (2014) argued that the demand for dollars as a reserve currency has led the US to run a huge current account deficit and resulting global imbalances. Sinn (2017) argued that the appreciation in the UK and US could be associated with their attractive and developed financial sector, which attract investments from foreigners and weigh on their export sectors and hence make them run large trade deficits, whereas Altuzarra,Ferreiro, and Serrano (2010) argued that the trade imbalances are due to structural changes in the current national and international supply and

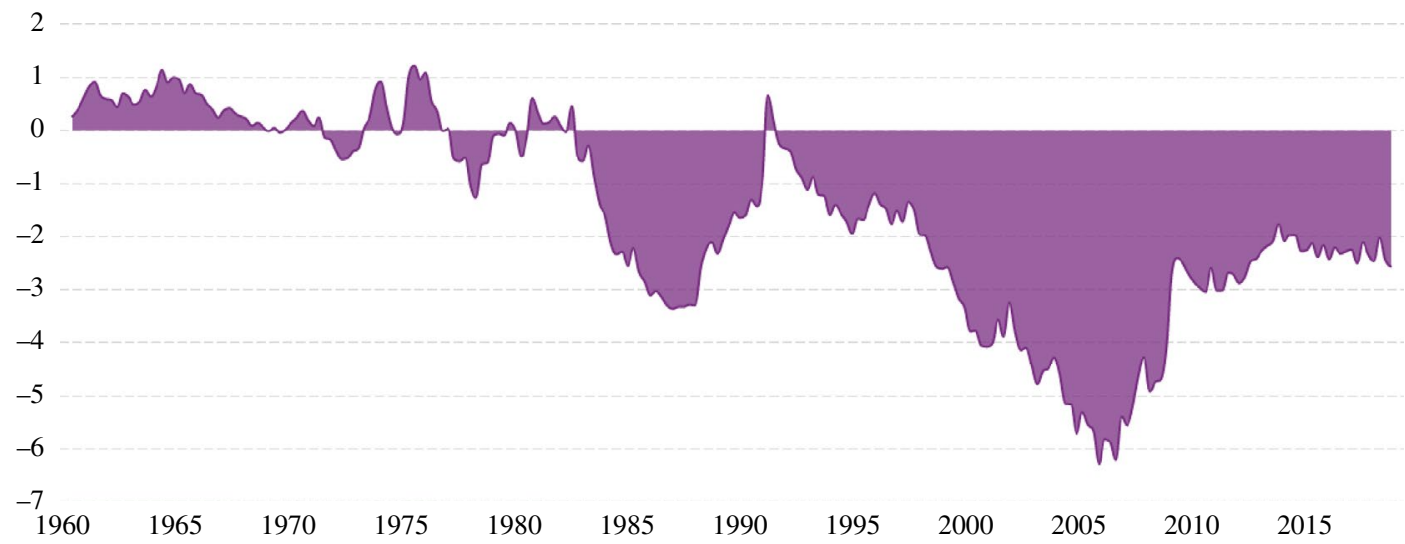

F I G URE 1 US current account balance: \% of GDP from March 1960 to December 2018 Source: CEIC.

${ }^{1}$ Under the US Trade Facilitation and Enforcement Act (2015), China, Germany, Japan, Taiwan and Korea have been put on watch list for the potential currency manipulator countries. 
demand patterns, and in fact, the US trade deficit was financed by the capital flows from some of the large oil exporters and emerging (surplus) economies (Altuzarra et al., 2010; Ito, 2008). Low international interest rate as a result of the large supply of saving in the Far East, e.g., China, is responsible for the massive US trade deficits (Bernanke, 2005). Nevertheless, there are a number of other influential factors, for instance, structural changes, trade policy technological progress and/ or monetary and fiscal policies (see Lee et al., 2006; Loeffler, 2015; Saadaoui, Mazier, \& Aflouk, 2013; Yue, Qiang, \& Kai, 2016). Reduction in values of money through inflation can also influence trade balance (Hume, 1742; Stockman, 1985). On the other hand, a rise in government spending may encourage more import but less export (Bahmani-Oskooee \& Payesteh, 1993). In terms of dealing with trade imbalances, Sinn (2017) suggested that the US and Eurozone should have a well-disciplined fiscal stance. However, these assertions and underlying factors held responsible for trade imbalances as suggested by various studies are required to be tested in the context of the US trade deficit. Therefore, contextualising on the debate on US trade deficit and resulting trade war and capitalising on the studies briefly acknowledged in this paragraph (and next section on determinants of trade balance), the objective of this study was to empirically explore the impact of real exchange rate dynamics and other determinants on US trade balance.

To reiterate, the global imbalances are often exploited for political gains and therefore have significant political implications.Reinhart (2017) argued that since the 1980s, Japan, China and lately Germany have been accused by the US for its trade deficits. Similarly, criticising current US administration stance on Germany and China, Sachs (2017) declared it to be the lack of US savings rather than the unfair trade policy by Germany and China. Similarly, Zhang and Sato argued that Chinese renminbi should not be blamed for the US deficit. However, earlier studies suggest that the changes in US productivity were the main determinants of the US trade position (Kollmann, 1998). ${ }^{2}$ Putting the political debate aside, one shall look at the empirical evidence to see which are the actual critical factors deriving trade balance in the US. Concomitantly, the main objectives of this study were to contextualise the debate on the US trade balance and look at the effects of the key macroeconomic factors on the US trade balance while accounting for the short long-term differences and asymmetries and non-linearities. In so doing, we employed a non-linear autoregressive distributed lag (NARDL) model on the US quarterly data from 1994 Q1 to 2018 Q1. This study aimed to determine whether the crucial domestic macroeconomic factors such as personal saving, effective real exchange rate, domestic inflation (GDP deflator), fiscal discipline and productivity also influence the US trade balance and to what extent. Our key findings suggest significant evidence of short- and long-run asymmetries between the exchange rate, US trade balance and its determinants. We found significant evidence of an asymmetric J-curve. Furthermore, our empirical results showed that the price deflator, productivity, domestic savings and fiscal deficit/discipline are crucial for US trade balance in the short and long term. The subject study contributes to the debate on the US trade deficit and has profound policy implications for the competitiveness of the US economy and its external balance.

The rest of the paper is organised as follows. Section 2 briefly reviews the existing evidence on the determinants of the trade balance to contextualise the debate on global imbalances and US trade deficit. A non-linear autoregressive distributed lag (NARDL) model is set out in Section 3. The empirical findings and discussion are found in Section 4. Finally, Section 5 concludes and discusses policy implication.

${ }^{2}$ Productivity can also have implications for the exchange rate, though empirical evidence is inconclusive (Chinn, 2000). 
In this treatise, the potential determinants of the trade balance we are focusing on are real effective exchange rate, domestic savings, domestic price levels, fiscal discipline/deficit and productivity, starting with the exchange rate that is perhaps the most debated determinant of the global imbalances. For years, exchange rate has been viewed as an effective tool in adjusting trade imbalance. The logic of exchange rate and the trade balance nexus is embedded in the notion that the exchange rate appreciation makes tradable domestic goods and services more expensive for overseas markets, while import goods and services become more affordable and vice versa. If such a scenario prevails, government interventions, analogous to those made by the US (discussed in Introduction), through tariff may be required to correct the issue. Yet, there is often a delay in the materialisation of exchange rate impact, manifested in the fact that the prices of previous purchase orders or contracts that have already been agreed do not change contemporaneously, a phenomenon known as the J-curve where the correction of the trade balance should be observed in the long run. ${ }^{3}$ For the adjustment of trade balance through appreciation and depreciation, one can go as far back as Hume's (1742) price-specie flow mechanism argument. The empirical studies since then often support a significant relationship between exchange rate and trade balance (Baharumshah, 2001; Bahmani-Oskooee et al., 2019; Bahmani-Oskooee \& Ratha, 2004; Bahmani-Oskooee \& Saha, 2017; Nasir \& Simpson, 2018; Stucka, 2004). However, the net benefit of depreciation (appreciation) can only be positive (negative) if the elasticities of export and import sum up to a value greater than unity, i.e., Marshall-Lerner condition (see BahmaniOskooee et al., 2019; Bahmani-Oskooee Ratha, 2004; Bahmani-Oskooee \& Saha, 2017; Devereux, 2000). Hence, on the depreciation, there is mixed evidence supporting the role of depreciation in improvements in trade balances (see Bahmani-Oskooee, 1991; Bahmani-Oskooee and Wang, 2006; Bahmani-Oskooee \& Ratha, 2004; Bahmani-Oskooee et al., 2019; Bahmani-Oskooee, Harvey, \& Hegerty, 2013; Bahmani-Oskooee and Hegerty, 2011; Bahmani-Oskooee \& Baek, 2016; BahmaniOskooee \& Saha, 2017; Hassan, Wajid, \& Kalim, 2017; Himarios, 1989; Lee \& Chinn, 2006; Yildirim and Ivrendi, 2016; Zhang \& Sato, 2012) and also indicating a lack of evidence on such a nexus, for instance, seminal work by Rose (1991) and Rose and Yellen (1989) or, more lately, Liew, Lim, and Hussain (2000), Shahbaz, Jalil, and Islam (2012) and Wang, Lin, and Yang (2012). However, the empirical evidence on such an impact is also mixed and contrasting; for instance, after analysing 87 countries, Bleaney and Tian (2014) reported that the industrial countries are slower in the adjustment of trade balance after a fall of the exchange rate. Similarly, Bahmani-Oskooee and Kutan's (2009), Bahmani-Oskooee et al. (2019) and Narayan (2006) also reported mixed results on the presence of the $J$-curve in various economies.

There is a notion that the exchange rate flexibility significantly affects the adjustment of trade balance (Ghosh, Qureshi, \& Tsangarides, 2013), although the empirical evidence does not always support the idea that a flexible exchange rate regime would facilitate current account adjustment (Chinn \& Wei, 2013). Studies, for instance, Falk (2008), further suggest that the depreciation of effective exchange rate become less efficient in trade balance improvement to countries that have already trade balance deficit. As it is prima facie evident that the US has a persistent trade deficit, so can the depreciation help? In fact, a recent study by Begović and Kreso (2017) shows small open (European transition) economies may experience an adverse effect of the effective exchange rate on the trade balance. They argued that this is due to the reason that while the depreciation of currency encourages export, small economies that do not have substitutes for imports or unable to increase export capacity will not see the effect of

${ }^{3}$ Initially, deterioration was observed, but after that, improvement in the trade balance was observed due to exchange rate depreciation forming a J-curve response (Bahmani-Oskooee and Ratha, 2004; Bahmani-Oskooee et al., 2019). 
the exchange rate change on the trade balance. However, the wider evidence from developed and developing economies also suggests that it is not always the case the depreciation helps to improve the trade balance (Liew et al., 2000; Rose, 1991; Shahbaz et al., 2012; Wang et al., 2012). Employing non-linear approaches, Arize, Malindretos, and Igwe (2017) found evidence of significant trade balance improvements in eight countries (excluding the US) after depreciation of their currencies. However, specific to the US, Chiu, Lee, and Sun (2010) analysed the bilateral trade balance with a number of countries and reported mixed results, while Devereux and Genberg (2007) argued that the appreciation by Asian economies can do very little to US current account reduction. Concomitantly, it would be intuitive to look at the holistic picture and incorporate the overall trade balance of the US while accounting for the non-linearities and asymmetries and additional indicators such as saving rate (Bahmani-Oskooee \& Fariditavana, 2015, 2016; Bahmani-Oskooee \& Nasir, 2019; Chiu \& Sun, 2016).

Saving rate increases the supply of loanable funds, which leads to a fall of interest rates. This results in an increase in both domestic investment and net capital outflow. Therefore, improving the saving rate may facilitate the elimination of trade imbalance (Arize, Bonitsis, Kallianiotis, Kasibhatla, \& Malindretos, 2000; Chiu \& Sun, 2016). Furthermore, as the export revenue increases, the reliance on foreign capital decreases, resulting in even higher domestic savings, a pattern that found commonly in strong export developing countries (Kandil, 2009).

Bernanke (2005) and Lee et al. (2006) have very strongly argued that the huge saving in East Asia, particularly in China, has distorted global interest rate had led to a drastic decline in interest rates in the US. Savers find themselves worse off after falling of interest rate, and on the other hand, capital becomes cheaper to borrow this that encourages more inflow of capital to finance import consumption and a low level of domestic saving. Some subsequent empirical studies rendered support to Bernanke's view (e.g., Caballero et al., 2008; Mendoza, Quadrini, \& Rios-Rull, 2009; Steinberg, 2018). Further, on this channel, Blanchard and Milesi-Ferretti (2012) argued that the export-led countries through macroeconomic policy interventions achieve high saving rate and low domestic demand. This encourages domestic firms to seek export opportunities for expansion. Domestic currency depreciates under low-interest rate making the products more competitive in the global market and trade figure of import countries worse off. On the other hand, intuitively, some studies have rather focused on the saving as a domestic issue and argued that the low domestic net savings are blamed on US massive trade deficits (e.g., Chinn \& Ito, 2008; Feldstein, 2008; Laibson \& Mollerstrom, 2010). A remarkable study on the global savings glut by Chinn and Ito's (2007) employed data of 19 industrial and 70 developing countries from 1970 to 2004 . Their empirical result did not provide strong support to the claims of Bernanke that high saving in East Asia has caused the deterioration of US trade balance; rather, it is budget deficit causing a decrease in personal saving that partly contributes to trade deficit. Hence, it is cogent to include the domestic savings into the analysis and the budgetary stance.

Fiscal policy is an important tool for the adjustment of the trade balance. Faced with a trade deficit, a contractionary stance would see a reduction in consumption of both imported and domestic goods and services. As the domestic market shrinks, domestic firms focus on foreign markets and successful ventures may lead to improvements in the trade balance. On the other hand, increased public spending drives up wages and prices and reduces personal saving. Imports increase after increase in income, leading to an increase in the budget deficit. An undesirable potential outcome of the budget deficit is that fall in public saving below domestic investment implies more money to be borrowed from aboard. The empirical evidence shows that government budgetary stance plays a significant role in inflicting current account balance (Baxter, 1995), i.e., twin deficits hypothesis, a twin deficit that the US has experienced since the early 2000s where it has seen an increase in budget deficit and deterioration in trade balance (Cavallo, 2005; Corsetti and Müller, 2006). There had been concerns raised the expansionary fiscal policy employed by the US administration would worsen what had been already a wide trade deficit in 
the pre-Global Financial Crisis era (Chinn, 2005). These concerns were disagreed by Ferguson (2004) and Greenspan (2005a, 2005b) arguing that at least in short-run, the twin deficit does not exist (also see Kim \& Roubini, 2008). Denying the twin deficit, it was argued that due to an increase in budget deficit, expecting a future tax increase private sector increase savings, increased government borrowing also pushes the interest rate up leading to decreased demand of imports, as a result current account improves. On this aspect, Erceg, Guerrieri, and Gust (2005) found low responsiveness of prices and switching cost between domestic and imported goods have eliminated the effects of budget deficit on the trade deficit. However, with the benefit hindsight, this seems not the case, the US trade deficit reached a record all-time in 2006. Nonetheless, some of the studies (e.g., Bernheim, 1988; Chinn \& Ito, 2008; Chinn \& Prasad, 2003) argued that the budget deficit partly contributes to the massive trade deficit. In this regard, evidence from EU countries (Beetsma, Klaassen, \& Giuliodori, 2008) also reported significant dual deficit hypothesis in EU economies as their North American counterpart. Hence, it is cogent to include the budget deficit into our analysis to see how much it contributes to the US trade deficit.

The domestic price levels are important factors in determining the price competitiveness of open economies. This aspect was at the forefront of Hume's (1742) argument that the increased supply of the gold (accumulated through trade surplus) will lead to increase in the domestic prices, which will discourage exports and encourage imports and in so doing will lead to adjustment of the trade balance. Concomitantly, inflation can have dramatic effects on the direction and the volume of international trade (Stockman, 1985). In specific to the trade deficits EMU peripheral states, Sinn (2014) argued that the high rates of domestic inflation had deteriorated the competitiveness of these economies, which led to high trade deficits. However, the evidence is contrasting as a recent study by Yiheyis and Musila (2018) reported a very little effect of inflation on the trade balance. Hence, in this study, we are considering the impact of domestic inflation (GDP deflator) on US trade balance to see whether the cause of huge trade deficit is due to increase in domestic price levels, which may erode the international competitiveness of US economy.

Improved productivity shall play a role in determining trade balance. Ghosh, Qureshi, and Tsangarides (2014) suggested that the dynamic relationship between productivity and trade balance may offer an alternative tool to adjust trade deficit to countries with less flexible or fixed exchange rate regime. A study by Bussière, Fratzscher, and Müller (2010) reported that the productivity and budget deficit are key determinants of current account balances in OECD countries, though there are country-wise differences. Batra and Beladi (1999) argued that the exporting countries that have a large manufacturing base are able to absorb new inventions and materialise them into production. This leads to high productivity and can explain the trade balance. However, this line of reasoning explaining nexus between productivity and trade balance is at odds with some of the examples in the real world; for instance, it does not explain the impressive trade surplus that China currently enjoys, which as compared to the US has unimpressive productivity. As the neoclassical growth model suggests, productivity growth affects both investment and consumption and overarchingly aggregate output. The demand for foreign goods and services increases as the wealth increases. This puts pressure on the trade balance. However, the results may vary among countries depending on various factors, e.g., productivity in trade and non-tradable sectors and/or home bias. On this aspect, some empirical studies support the notion that there is a negative link between productivity and trade deficit (Chen, İmrohoroğlu, \& İmrohoroğlu, 2009; Engel \& Rogers, 2006). Kollmann (1998) focusing on the US and G-6 argued that US productivity shocks were the most dominating factor for the US trade balance. In a later study, Ferrero (2010) argued that productivity growth differentials significantly influence the US trade balance and all of its dynamics. Specifically, the attractiveness of the US for foreign resources and increased consumption leads to the trade deficit. However, it was also argued that as the consumption is decreased and savings are increased to repay the foreign liabilities, the trade deficit decreases. This fuels the rationale for the subject study where we are intending to analyse the implication of 
productivity, savings and the exchange rate, domestic inflation and fiscal discipline for the US trade balance in a framework, which accounts for the potential non-linearities and asymmetries.

\section{3 | METHODOLOGY}

A non-linear autoregressive distributed lag (NARDL) framework is employed to estimate and analyse the shocks to the US trade balance caused by its potential determinants, namely real effective exchange rate, saving, budget deficit/surplus, productivity and GDP deflator. The novelty of this framework is that it takes into account the asymmetries and non-linearities in the relationship between the explanatory and response variables. Furthermore, it provides insight into the long- and the short-run relationship among the variables of interest (Bahmani-Oskooee \& Nasir, 2019). This relationship can be specified in the following form:

$$
T B_{t}=\beta_{T B} T B_{t-i}+\beta_{E x} E x_{t-i}+\beta_{P D} P D_{t-i}+\beta_{S A V} S A V_{t-i}+\beta_{B U D} B U D_{t-i}+\beta_{P R O D} \operatorname{Prod}_{t-i}+e_{t}
$$

where the trade balance $(T B)$ is determined by its past values (persistence element, $T B_{t-i}$ ), determinants, i.e., real exchange rates $(E X)$; price deflator $(P D)$, a proxy for domestic inflation and price stability; savings $(S A V)$; budget deficit/surplus $(B U D)$ for fiscal discipline; and productivity (Prod), given that these factors are theoretically perceived to be the crucial determinants of external balance.

To reiterate, the novelty of the employed NARDL approach is that it takes into account the asymmetries and non-linearities in the association between trade balance and its determinants. As we are interested in investigating these asymmetries and non-linearities in the context of US trade balance, NARDL is the logically appropriate framework of analysis. The NARDL cointegration approach is based on the seminal work by Shin, Yu, and Greenwood-Nimmo (2011), which found its roots in the contributions by Pesaran and Shin (1999) and Pesaran, Shin, and Smith (2001). To start with, we can specify the Equation (1) in the following long-run model of the trade balance:

$$
T B_{t}=a_{0}+a_{1} E X_{t}^{+}+a_{2} E X_{t}^{-}+a_{3} P D_{t}+a_{4} S A V_{t}+a_{5} B U D_{t}+a_{6} P R O D_{t}+e_{t}
$$

where $T B_{t}$ is trade balance, and its determinants are as specified earlier in Equation (1); however, $a=\left(a_{0}-a_{6}\right)$ is a cointegrating vector of long-run parameters. In Equations (3) and (4), the $E X_{t}^{+}$and $E X_{t}^{-}$ are partial sums of positive and negative changes in the exchange rate $\left(E X_{t}\right)$, and it can be specified as:

$$
E X_{t}^{+}=\sum_{i=1}^{t} \Delta E X_{i}^{+}=\sum_{i=1}^{t} \max \left(\Delta E X_{i}, 0\right)
$$

and

$$
E X_{t}^{-}=\sum_{i=1}^{t} \Delta E X_{i}^{-}=\sum_{i=1}^{t} \min \left(\Delta E X_{i}, 0\right)
$$

In the light formulation presented above (Equation 2), the relationship between trade balance $\left(T B_{t}\right)$ and exchange rate $\left(E X_{t}\right)$ is expected to be negative $\left(a_{1}\right)$. However, $a_{2}$ captures the association between trade balance and exchange rate while there is reduction or depreciation in the real effective exchange rate. Due to negative association, estimates of $a_{2}$ are expected to have positive signs.

Furthermore, we also posit that the exchange rate fluctuations have effects with some lags and follow $J$-curve behaviour. Nonetheless, in the case of asymmetric association between exchange rate and 
trade balance, the effects of appreciation would be different in magnitude from the depreciation. In simple words, the positive shocks will have a greater or smaller impact than the negative shocks, i.e., $a_{1} \neq a_{2}$. Concomitantly, the long-run relationship presented in the Equation (2) is expected to reflect an asymmetric exchange rate pass-through. At this juncture, we can frame Equations (2) and (3) into a NARDL setting (see, Pesaran \& Shin, 1999; Pesaran et al., 2001; Shin et al., 2011) as follows:

$$
\begin{gathered}
\Delta T B_{t}=a+\beta_{1} T B_{t-1}+\beta_{2} E X_{t-1}^{+}+\beta_{3} E X_{t-1}^{-}+\beta_{4} P D_{t-1}+\beta_{5} S A V_{t-1} \\
+\beta_{6} B U D_{t-1}+\beta_{7} P R O D_{t-1}+\sum_{i=1}^{p} \varnothing_{i} \Delta T B_{t-i}+\sum_{i=0}^{q}\left(\theta_{i}^{+} \Delta E X_{t-i}^{+}+\theta_{i}^{-} \Delta E X_{t-i}^{-}\right) \\
+\sum_{i=0}^{s} \gamma_{i} \Delta P D_{t-i}+\sum_{i=0}^{v} \delta_{i} \Delta S A V_{t-i}+\sum_{i=0}^{w} \Omega_{i} \Delta B U D_{t-i}+\sum_{i=0}^{x} \varphi_{i} \Delta P R O D_{t-i}+e_{t}
\end{gathered}
$$

wherewe have defined all the variables earlier and $p, \mathrm{q}, \mathrm{s}, \mathrm{v}, \mathrm{w} \& x$ arelag orders and $a_{1}=-\beta_{2} / \beta_{1} a_{2}=-\beta_{3} / \beta_{1}$ are the earlier mentioned long-run impacts of increase(appreciation)/decrease(depreciation) in the exchange rate on trade balance (Equation (5)). In Equation (5), the $\sum_{i=0}^{q} \theta_{i}^{+}$measures the short-run impacts of an increase in the exchange rate on the trade balance, whereas $\sum_{i=0}^{q} \theta_{i}^{-}$measures the short-run impacts of a decrease in the exchange rate on the trade balance. Concomitantly, in this setting, we capture the asymmetric long-run and the asymmetric short-run relationship between trade balance and exchange rate dynamics. The implementation of the employed NARDL framework will be entailed on the following steps. At first, we will perform the unit root test to determine the order integration of underlying data series. It is worth acknowledging that the ARDL approach to cointegration is valid whether the series are $I(0)$ or $I(1)$; however, it is still important to perform to unit root test to confirm that there is no $I(2)$ variable. This is an important aspect to consider as $I(2)$ invalidates the computation of F-statistics to test the cointegration (Ibrahim, 2015). We would perform the ADF unit root test with a structural break to find the order of integration. Thereafter, we would estimate Equation (5) using the OLS method. After estimation of our NARDL model, we would be applying the bound testing approach proposed by Pesaran et al. (2001) and Shin et al. (2011) to test cointegration among underlying data series. In so doing, we would perform the Wald $F$ test with the null hypothesis, $\beta_{1}=\beta_{2}=\beta_{3}=\beta_{4}=\beta_{5}=\beta_{6}=\beta_{7}=0$.In the last and final step of the analysis, we would examine the long- and short-run asymmetries in the relationship between trade balance and exchange rate dynamics, and we would also discuss the impact of other explanatory variables in the model. With specific to the US trade balance and exchange rate, we would derive the asymmetric cumulative dynamic multiplier effects of a $1 \%$ change in the exchange rate, i.e., $E X_{t-1}^{+}$and $E X_{t-1}^{-}$, respectively, as:

$$
m_{h}^{+}=\sum_{j=0}^{h} \frac{\partial y_{t+j}}{E X_{t-1}^{+}}, m_{h}^{-}=\sum_{j=0}^{h} \frac{\partial y_{t+j}}{E X_{t-1}^{-}}, h=0,1,2
$$

A point to note here is that as $h \rightarrow \infty, m_{h}^{+} \rightarrow a_{1}$ and $m_{h}^{-} \rightarrow a_{2}$.

\section{I DATA SET}

In this study, NARDL framework was employed on the quarterly data from 1994: Q1 to 2018: Q1. The choice of time horizon is informed by the viability of data, particularly on the real effective exchange rate measure. The details of each variable and proxy are attached as the Appendix. 
T A B L E 1 ADF test with structural break: Additive and innovative outliers

\begin{tabular}{|c|c|c|c|c|c|}
\hline & Variables & $\begin{array}{l}\text { ADF test } \\
\text { statistic (IO) }\end{array}$ & $\begin{array}{l}p \text { - } \\
\text { Values }\end{array}$ & $\begin{array}{l}\text { ADF test statistic } \\
\text { (AO) }\end{array}$ & $\begin{array}{l}p \text { - } \\
\text { Values }\end{array}$ \\
\hline \multirow[t]{6}{*}{ Level } & Trade balance & -3.801 & .648 & -3.895 & .591 \\
\hline & $\begin{array}{l}\text { Real effective exchange } \\
\text { rate }\end{array}$ & -2.753 & .985 & -2.759 & .958 \\
\hline & Price deflator & $-5.418^{* *}$ & .026 & -4.767 & .134 \\
\hline & Savings & $-5.176^{* *}$ & .049 & $-5.839^{*}$ & $<.01$ \\
\hline & Budget deficit/surplus & $-6.922^{*}$ & $<.01$ & $-7.076^{*}$ & $<.01$ \\
\hline & Productivity & $-11.218^{*}$ & $<.01$ & $-11.450^{*}$ & $<.01$ \\
\hline \multirow[t]{6}{*}{ 1st difference } & Trade balance & $-12.210^{*}$ & $<.01$ & $-12.337^{*}$ & $<.01$ \\
\hline & $\begin{array}{l}\text { Real effective exchange } \\
\text { rate }\end{array}$ & $-8.386^{*}$ & $<.01$ & $-8.495^{*}$ & $<.01$ \\
\hline & Price deflator & $-7.934^{*}$ & $<.01$ & $-8.084^{*}$ & $<.01$ \\
\hline & Savings & $-15.727^{*}$ & $<.01$ & $-15.989^{*}$ & $<.01$ \\
\hline & Budget deficit/surplus & $-14.816^{*}$ & $<.01$ & $-22.131^{*}$ & $<.01$ \\
\hline & Productivity & $-18.556^{*}$ & $<.01$ & $-19.299^{*}$ & $<.01$ \\
\hline
\end{tabular}

$* 1 \%$ level of significance.

$* * 5 \%$ level of significance.

***Vogelsang (1993) asymptotic one-sided $p$-values.

\section{5 | ANALYSIS AND FINDINGS}

Prior to estimation, a unit root test is performed to determine the order of integration of underlying data series. For this purpose, theADF unit root test with the structural break is employed. Accounting for the structural break is vital to avoid the risk of bias towards null of random walk (see Hansen, 2001; Perron, 1989, 2006; Ranganathan \& Ananthakumar, 2010). We let the data speak, and instead of exogenously determining the date of the break, it was left to be determined endogenously. In so doing, we choose the alternative minimise and maximise options to allow for evaluation of one-sided alternatives, this produces different critical values for the final Dickey-Fuller test statistic and tests with greater power than the non-directional alternatives. ${ }^{4}$ The ADF is applied to test for the unit root in the presence of break with both innovative outliers (IO) and additive outliers (AO). ${ }^{5}$ To choose the optimal number of lags for the ADF test, we used the Schwarz information criteria (SIC), which is particularly appropriate in the presence of structural break (Asghar and Abid, 2007). The results are presented in Table 1.

The results of the unit root test with structural break and including innovative and additive outliers presented above suggest that for some of the series (trade balance and real effective exchange rate), the null of no unit root could not be rejected at a statistical level of significance, although budget deficit/surplus was found to be stationary at the level indicating the long-term economic and budgetary stability of the United States. However at the first difference, all the serious were found to

\footnotetext{
${ }^{4}$ For a detailed discussion and support of this practice, please see Banerjee, Lumsdaine, and Stock (1992), Vogelsang and Perron (1998) and Zivot and Andrews (1992).

${ }^{5}$ See Fox (1972) and Tsay (1988) for a detailed discussion and classification of "additive outliers (AO)" and "innovative outliers (IO)”.
} 
be stationary, i.e., I (1). For the structural break in the US trade balance, we examined the DickeyFuller t-stats and the Dickey-Fuller autoregressive coefficients for US trade balance series using additive and innovative outliers. The results indicated the presence of a structural break around the Global Financial Crisis (GFC). ${ }^{6}$ This is intuitive if we consider the major disruption for international trade due to the GFC 2007-08. After unit root testing, we come to the estimation of NARDL model (Equation (5)).

\section{BOUND TESTING FOR NON-LINEAR COINTEGRATION}

Table 2 presents the results of bound testing for the non-linear cointegration.

The bound testing showed that the critical values of the $F$-statistics were greater than upper bound at $95 \%$ level of confidence. In fact, the results were even significant at $99 \%$ indicating strong evidence of cointegration in the model models (Equation (5)), although, in line with the common practice, our benchmark is $95 \%$. This implied that there is a long-run relationship between the under analysis variables, and hence, we can proceed with the estimation and further analysis. The results of non-linear ARDL are presented in Table 3.

The estimation results of NARDL model present the evidence of asymmetries and non-linearities in the relationship between US trade balance and exchange and other determinants of the trade balance in both the short and long run. To start with, we can witness the evidence of the self-correcting mechanism in the trade balance as the lagged value of trade balance $\left(T B_{t-1}\right)$ showed a negative and significant impact. On the other hand, the exchange rate showed evidence of asymmetry as the lagged positive exchange rate $\left(E X_{t-1}^{+}\right)$shocks had a negative and significant while the negative $\left(E X_{t-1}^{-}\right)$shock also had a negative but insignificant impact. The price deflator and productivity showed negative and significant impacts with one lag, implying that the increase in the price level or inflation decreases the competitiveness of US and deteriorates the trade balance. The lagged savings and budget (surplus/ deficit) had a positive impact, which implied that the increased savings and fiscal discipline can lead to the improvements in the trade balance, though the results were not highly significant. The short-run estimates of the positive shocks to the exchange rate $\left(\Delta E X_{t}^{+}\right)$showed a negative, while the negative shocks or depreciation $\left(\Delta E X_{t-1}^{-}\right)$had strong positive and significant effects on the trade balance, suggesting the short-term asymmetries and non-linearities. The price deflator had a contemporaneous negative effect, though they were not very significant and varied with lags. Interestingly, the productivity showed short-term positive effects on the trade balance, which were also highly significant. This implied that the productivity improvements can lead to short-term trade balance improvements. The savings and budget surplus/deficit showed short-term negative but insignificant effects on the trade balance. The error correction term $(\mathrm{ECT})$ is found to be negative $(-0.192)$ and high significant

TA B L E 2 Bound test for the non-linear cointegration

\begin{tabular}{llllll} 
Dependent variable & $\boldsymbol{F}$-statistics & $\boldsymbol{K}$ & $\begin{array}{l}\text { Lower bound } \\
(\mathbf{9 5 \%})\end{array}$ & $\begin{array}{l}\text { Upper bound } \\
(\mathbf{9 5 \%})\end{array}$ & Conclusion \\
\hline TradeBalance $\left(T B_{t}\right)$ & $4.211^{*}$ & 6 & 2.27 & 3.28 & Cointegration \\
\hline
\end{tabular}

$* 1 \%$ level of significance.

$* * 5 \%$ level of significance.

$* * * 10 \%$ level of significance.

${ }^{6}$ Results are concealed to conserve the space but can be provided upon request. 
T A B L E 3 Non-linear ARDL estimation of US trade balance

\begin{tabular}{|c|c|c|}
\hline Variables & Coefficient & Prob. \\
\hline \multicolumn{3}{|l|}{ Panel A: short-run estimates } \\
\hline$T B_{t-1}$ & -0.192 & $.000^{*}$ \\
\hline$E X_{t-1}^{+}$ & -1.156 & $.037^{* *}$ \\
\hline$E X_{t-1}^{-}$ & -0.936 & .112 \\
\hline$P D_{t-1}$ & -0.260 & $.014^{*}$ \\
\hline Productivty $_{t-1}$ & -0.109 & $.011^{*}$ \\
\hline Savings $_{t-1}$ & 0.011 & .362 \\
\hline Budget $_{t-1}$ & 0.04 & .377 \\
\hline$\Delta E X_{t}^{+}$ & -0.594 & .809 \\
\hline$\Delta E X_{t-1}^{-}$ & 5.952 & $.024^{*}$ \\
\hline$\Delta P D_{t}$ & -0.109 & .417 \\
\hline$\Delta P D_{t-1}$ & 0.071 & .612 \\
\hline$\Delta P D_{t-2}$ & 0.385 & $.003^{*}$ \\
\hline$\Delta$ Productivty $_{t}$ & 0.034 & $.011^{*}$ \\
\hline$\Delta$ Productivty $_{t-1}$ & 0.115 & $.000^{*}$ \\
\hline$\Delta$ Productivty $_{t-2}$ & 0.089 & $.001^{*}$ \\
\hline$\Delta$ Productivty $_{t-3}$ & 0.069 & $.001^{*}$ \\
\hline$\Delta$ Productivty $_{t-4}$ & 0.036 & $.008^{*}$ \\
\hline$\Delta$ Savings $_{t}$ & -0.012 & .333 \\
\hline$\Delta$ Budget $_{t}$ & -0.015 & .578 \\
\hline$\Delta$ Budget $_{t-1}$ & -0.043 & .126 \\
\hline Constant & 0.012 & .974 \\
\hline ECT & -0.192 & $.000^{*}$ \\
\hline \multicolumn{3}{|l|}{ Panel B: long-run estimates } \\
\hline$E X^{+}$ & -6.007 & $.033^{* *}$ \\
\hline$E X^{-}$ & -4.866 & .103 \\
\hline Price deflator & -1.351 & $.001^{*}$ \\
\hline Productivity & -0.570 & $.002^{*}$ \\
\hline Savings & 0.062 & .337 \\
\hline Budget & 0.208 & .291 \\
\hline \multicolumn{3}{|l|}{ Panel C: diagnostic testing } \\
\hline$R^{2}$ & .969 & \\
\hline$F$ test & 111.174 & $.000^{*}$ \\
\hline Jarque-Bera (JB) residual normality test & 0.968 & .616 \\
\hline Breusch-Godfrey (BG)LM test & 0.069 & .965 \\
\hline Durbin-Watson test & 1.985 & \\
\hline Breusch-Pagan-Godfrey (BPG) test & 27.701 & .116 \\
\hline White test & 28.493 & .098 \\
\hline Ramsey RESET test & 1.191 & .237 \\
\hline
\end{tabular}

Note: : Huber-White-Hinkley heteroscedasticity-consistent standard errors and covariance.

$* 1 \%$ level of significance.

$* * 5 \%$ level of significance.

*** $10 \%$ level of significance, BG LM test with two lags for autocorrelation. 


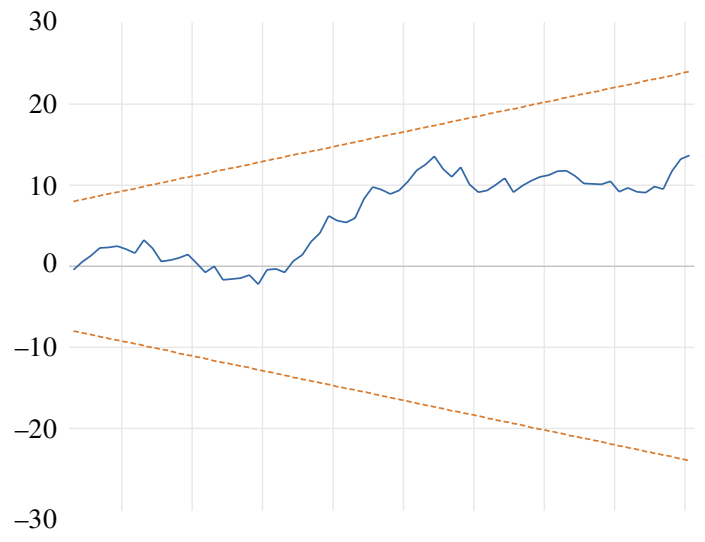

200020022004200620082010201220142016

- CUSUM ---- 5\% Significance

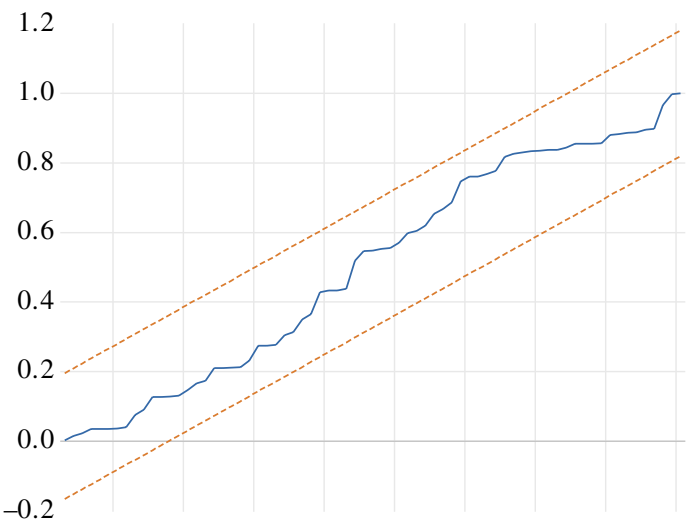

200020022004200620082010201220142016

- CUSUM of squares ---- 5\% Significance

F I G U RE 2 CUSUM and CUSUMSQ parameter stability test for the US trade balance

suggesting the stability of the model and pace of adjustment. The long-run estimates of our NARDL model presented in the Panel B suggest that the positive exchange rate shocks or appreciation $\left(E X^{+}\right)$ has strong negative and highly significant effects on the trade balance. On the other hand, the negative shocks or depreciation $\left(E X^{-}\right)$had also a negative but insignificant impact. This not only indicates the asymmetry in the nexus between exchange rate trade balances but also suggests that the long-run improvements of trade balance may not be possible by mere exchange rate depreciation. The price deflator showed a very strong negative and significant impact on the trade balance, which implied that the inflation significantly reduces the competitiveness of the US economy and worsens the trade balance. The productivity also showed a negative and significant impact on the trade balance in the long run, this implies that the increase in the productivity that may lead to higher income increases the demand for the foreign goods and hence reduces the US trade balance in the long run. The savings and budget (surplus/deficit) showed a positive impact, indicating the importance of savings and fiscal discipline for the US trade balance. Lastly, we performed the dialogistic test to check the robustness of our model and estimates. It showed that the estimates are very robustness. The $R^{2}$ and $F$ test showed high and significant values, which implied the overall significance of the model. Nonetheless, the Jarque-Bera (JB) residual normality test showed that the null of normality was not rejected at the $5 \%$ level of significance ( $p$-value .616 > .05). Similarly, the Breusch-Godfrey (BG) LM test and Durbin-Watson test suggest that the null of no autocorrelation was not rejected at $5 \%$ level of significance. The BreuschPagan-Godfrey (BPG) test and White test were performed to check for the heteroscedasticity. The results showed that the null of no heteroscedasticity was not rejected at the $5 \%$ level of significance. Lastly, we performed the Ramsey RESET test to check for the misspecification and the null of no misspecification was not rejected. Concomitantly, in nutshell, we can conclude that our estimates are robust against all the diagnostic tests including non-normality, autocorrelation, heteroscedasticity and misspecification. However, in order to test the stability of our model, we performed the CUSUM and CUSUMSQR parameter stability test. The results are presented in Figure 2.

The parameter stability test for the US trade balance showed that our estimates are stable. After the stability test, we estimate the multiplier effects of real effective exchange rate dynamics on the US trade balance. The results of the NARDL cumulative multiplier impact analysis of the real effective exchange rate are presented in Figure 3. 
$12 \%$

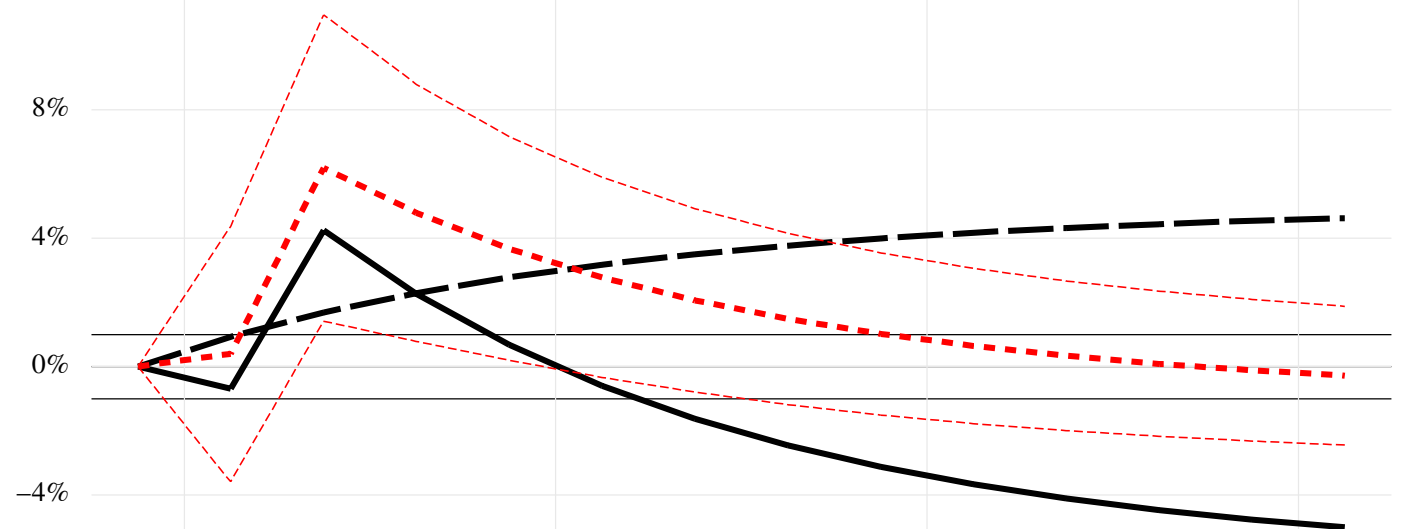

$-8 \%$

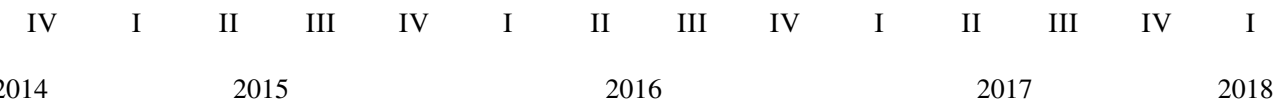

LNBOARDEXCHANGE $+1 \%$ - LNBOARDEXCHANGE - $1 \%$ -

F I G U RE 3 NARDL multiplier of real effective exchange rate and response of US trade balance

The NARDL multiplier effects of real effective exchange rate dynamics for the US trade balance showed very interesting results. The positive shock to the real effective exchange rate or an appreciation of US\$ (1\%) showed initial improvement but then consistent deterioration of the trade balance. This is clear evidence of the $J$-curve behaviour, in case of an increase or appreciation of US\$. However, the negative shock to the real effective exchange rate led to a consistently positive response from the trade balance, implying that the depreciation of the US\$ leads to improvement in the US trade balance. But it is also worth noting that the impact of exchange rate shocks is not symmetric as the positive and negative shocks transmit differently. Collectively, there is prima facie evidence of an asymmetric $J$-curve behaviour of the trade balance in response to the real effective exchange rate dynamics.

\section{7 | CONCLUSION}

The global trade imbalances is a topic, which never lost its significance in international economics and political economy. This holds true today where the world largest economy is also the largest deficit nation. Concomitantly, it has led to a heated debate and calls for the "trade wars" and accusations of competitive devaluations. However, the impact of macroeconomic factors that influence the trade balance adjustment is complicated and interrelated. Keeping this debate in context, we investigated the determinants of US trade balance in a framework, which does account for the asymmetric and non-linear effects of exchange rate dynamics for the US trade balance. Our empirical findings and facts on the ground lead us to conclude that there is significant evidence of short- and long-run asymmetries between the exchange rate, US trade balance and its determinants. We found the evidence of 
an asymmetric J-curve. The depreciation can be beneficial to the US trade balance, which implies that the US trade deficit is related to the exchange rate pass-through to which the US has more influence. Furthermore, our empirical results lead us to conclude that the domestic inflation (GDP deflator), productivity, domestic savings and fiscal discipline are crucial for US trade balance in the short to long term. Specifically, domestic inflation (GDP deflator) and price stability is an important factor, which erodes the US international competitiveness trade balance. There could be some short-term gains through improvements in the productivity; however, in the long run, it also leads to negative effects, which are in line with the literature. The fiscal discipline and private savings are also found to be important factors, which can facilitate the correction of the US trade deficit. The findings of this study contribute to the debate on the US trade deficit and have profound policy implications for the competitiveness of the US economy and its external balance. Specifically, it shows that the trade balance improvement cannot be attributed to one single macroeconomic factor. Stabilisation policies that can facilitate an increase in savings, fiscal discipline, and domestic price stability can act as critical facilitators within a plan of correcting US trade imbalance over the long run. Such a stabilisation should be gradual as sharp stance can have unattended consequences for the global economy. Putting the politics of trade wars aside, the policymakers should be aware of the inter-relationship between these factors and their individual and collective impact on the trade balance.

\section{DATA AVAILABILITY STATEMENT}

Data available on request from the authors.

\section{ORCID}

Muhammad Ali Nasir (iD https://orcid.org/0000-0003-2779-5854

\section{REFERENCES}

Altuzarra, A., Ferreiro, J., \& Serrano, F. (2010). The role of global imbalances as a cause of the current crisis. Journal of Innovation Economics \& Management, 2(6), 25-48.

Arize, A. C., Bonitsis, T. M., Kallianiotis, I. N., Kasibhatla, K. M., \& Malindretos, J. (2000). Balance of payment adjustments. Macro facets of international finance revisited. Westport, CT: Greenwood Press.

Arize, A. C., Malindretos, J., \& Igwe, E. U. (2017). Do exchange rate changes improve the trade balance: An asymmetric nonlinear cointegration approach. International Review of Economics and Finance, 49, 313-326.

Asghar, Z., \& Abid, I. (2007). Performance of lag length selection criteria in three different situations, MPRA Paper 40042. Munich, Germany: University Library of Munich. https://mpra.ub.uni-muenchen.de/40042/

Baharumshah, A. Z. (2001). The effect of exchange rate on bilateral trade balance: New evidence from Malaysia and Thailand'. Asian Economic Journal, 15(3), 291-311. https://doi.org/10.1111/1467-8381.00135

Bahmani-Oskooee, M. (1991). Is there a long-run relation between the trade balance and the real effective exchange rate of LDCs? Economics Letters, 36(4), 403-407.

Bahmani-Oskooee, M., \& Baek, J. (2016). Do exchange rate changes have symmetric or asymmetric effects on the trade balance? Evidence from U.S.-Korea commodity trade'. Journal of Asian Economics, 45, 15-30.

Bahmani-Oskooee, M., Bose, N., \& Zhang, Y. (2019). An asymmetric analysis of the J-curve effect in the commodity trade between China and the US. The World Economy, 42(10), 2854-2899. https://doi.org/10.1111/twec.12829

Bahmani-Oskooee, M., \& Fariditavana, H. (2015). Nonlinear ARDL approach, asymmetric effects and the J-curve. Journal of Economic Studies, 42, 519-530.

Bahmani-Oskooee, M., \& Fariditavana, H. (2016). Nonlinear ARDL approach and the J-curve phenomenon. Open Economies Review, 27, 51-70.

Bahmani-Oskooee, M., Harvey, H., \& Hegerty, S. W. (2013). Empirical tests of the Marshall-Lerner condition: a literature review. Journal of Economic Studies, 40(3), 411-443.

Bahmani-Oskooee, M., \& Hegerty, S. W. (2010). The J- and S-curves: A survey of the recent literature. Journal of Economic Studies, 37(6), 580-596. 
Bahmani-Oskooee, M., \& Kutan, A. M. (2009). The J-curve in the emerging economies of Eastern Europe. Applied Economics, 41(20), 2523-2532. https://doi.org/10.1080/00036840701235696

Bahmani-Oskooee, M., \& Nasir, M. A. (2019). Asymmetric J-curve: Evidence from industry trade between U.S. and U.K. Applied Economics, 52(25), 2679-2693. https://doi.org/10.1080/00036846.2019.1693700

Bahmani-Oskooee, M., \& Payesteh, S. (1993). Budget deficits and the value of the dollar: An application of cointegration and error-correction modeling. Journal of Macroeconomics, 15, 661-677.

Bahmani-Oskooee, M., \& Ratha, A. (2004). The J-curve: A literature review. Applied Economics, 36(13), 1377-1398.

Bahmani-Oskooee, M., \& Saha, S. (2017). Asymmetric response of the US-India trade balance to exchange rate changes: Evidence from 68 industries. The World Economy, 40(10), 2226-2254. https://doi.org/10.1111/twec.12521

Bahmani-Oskooee, M., \& Wang, Y. (2006). The J-curve: China versus her trading partners. Bulletin of Economic Research, 58, 323-343.

Banerjee, A., Lumsdaine, R. L., \& Stock, J. H. (1992). Recursive and sequential tests of the unit root and trend-break hypothesis: Theory and international evidence. Journal of Business and Economic Statistics, 10, 271-287.

Batra, R., \& Beladi, H. (1999). Manufacturing and the trade balance. Pacific Economic Review, 3(2), 121-131. https:// doi.org/10.1111/1468-0106.00046

Baxter, M. (1995). International trade and business cycles. In G. M. Grossman, \& K. Rogoff (Eds.), Handbook of international economics (Vol. 3, pp. 1801-1864). Amsterdam, the Netherlands: North-Holland.

Beetsma, R., Klaassen, F., \& Giuliodori, M. (2008). The effects of public spending shocks on trade balances and budget deficits in the European Union. Journal of the European Economic Association, 2(3), 414.

Begović, S., \& Kreso, S. (2017). The adverse effect of real effective exchange rate change on trade balance in European transition countries; Nepovoljan efekt promjena realnog efektivnog tečaja na trgovinsku bilancu u Europskim tranzicijskim zemljama. Zbornik Radova Ekonomskog Fakulteta U Rijeci, 35(2), 277-299.

Bernanke, B. S. (2005). The global saving glut and the U.S. current account deficit. Speech. Board of Governors of the Federal Reserve System.

Bernheim, B. D. (1988). Budget deficits and the balance of trade. In L. H. Summers (Ed.), Tax policy and the economy (Vol. 2, pp. 1-320). MIT. Retrieved from: http://www.nber.org/chapters/c10935.

Blanchard, O. J., \& Milesi-Ferretti, G. M. (2012). (Why) should current account balances be reduced? IMF Economic Review, 60, 139-150.

Bleaney, M., \& Tian, M. (2014). Exchange rates and trade balance adjustment: A multi-country empirical analysis. Open Economies Review, 25(4), 655-675.

Borio, C. (2016). On the centrality of the current account in international economics. Journal of International Money and Finance, 68, 266-274.

Briscoe, H. (2015). Rise of the RMB: Three reasons to expect China's currency to surge. Retrieved from https://cityw ire.co.uk/investment-trust-insider/news/rise-of-the-rmb-three-reasons-to-expectchina-s-currency-to-surge/a8106 87? section=global

Bussière, M., Fratzscher, M., \& Müller, G. J. (2010). Productivity shocks, budget deficits and the current account. Journal of International Money and Finance, 29(8), 1562-1579.

Caballero, R., Fahri, E., \& Gourinchas, P. O. (2008). An equilibrium model of 'global imbalances' and low interest rates. American Economic Review, 98, 358-393.

Cavallo, M. (2005). Understanding the Twin Deficits: New Approaches, New Results, Economic Letters, 2005-16, July 22, 2005. Retrieved from https://www.frbsf.org/economic-research/publications/economic-letter/2005/july/under standing-the-twin-deficits-new-approaches-new-results/.

Čerović, S., Pepić, M., Petrović, P., \& Čerović, S. (2014). The impact of the global financial crisis on world trade. Economic Themes, 52(1), 13-32.

Chakraborty, S., \& Dekle, R. (2009). Can international productivity differences alone account for the US current account deficits. Review of International Economics, 17(4), 689-715.

Chen, K., İmrohoroğlu, A., \& İmrohoroğlu, S. (2009). A quantitative assessment of the decline in the U.S. current account balance. Journal of Monetary Economics, 56, 1135-1147. https://doi.org/10.1016/j.jmoneco.2009.10.014

Chinn, M. D. (2000). The usual suspects? Productivity and demand shocks and Asia-pacific real exchange rates. Review of International Economics, 8(1), 20-43. https://doi.org/10.1111/1467-9396.00203

Chinn, M. D. (2005). Getting serious about the twin deficits. Council on Foreign Relations, Special Report No. 10. https://www.cfr.org/report/getting-serious-about-twin-deficits 
Chinn, M. D., \& Ito, H. (2007). Current account balances, financial development and institutions: Assaying the world 'saving glut. Journal of International Money and Finance, 26(4), 546-569. https://doi.org/10.1016/j.jimon fin.2007.03.006

Chinn, M. D., \& Ito, H. (2008). Global current account imbalances: American fiscal policy versus East Asian savings. Review of International Economics, 16(3), 479-498. https://doi.org/10.1111/j.1467-9396.2008.00741.x

Chinn, M. D., \& Prasad, E. S. (2003). Medium-term determinants of current accounts in industrial and developing countries: An empirical exploration. Journal of International Economics, 59(1), 47-76.

Chinn, M. D., \& Wei, S. J. (2013). A faith-based initiative meets the evidence: Does a flexible exchange rate regime really facilitate current account adjustment? Review Economics and Statistics, 95(1), 168-184. https://doi. org/10.1162/REST_a_00244

Chiu, Y.-B., Lee, C.-C., \& Sun, C.-H. (2010). The U.S. trade imbalance and real exchange rate: An application of the heterogeneous panel cointegration method. Economic Modelling, 27, 705-716. https://doi.org/10.1016/j.econm od.2010.01.011

Chiu, Y. B., \& Sun, C. (2016). The role of savings rate in exchange rate and trade imbalance nexus: Cross-countries evidence. Economic Modelling, 52, 1017-1025. https://doi.org/10.1016/j.econmod.2015.10.040

Corsetti, G., \& Müller, G. J. (2006). Twin deficits: Squaring theory, evidence and common sense. Economic Policy, 21(48), 597-638.

Devereux, M. B. (2000). How does a devaluation affect the current account? Journal of International Money and Finance, 19(6), 833-851.

Devereux, M. B., \& Genberg, H. (2007). Currency appreciation and current account adjustment. Journal of International Money and Finance, 26(4), 570-586.

Dooley, M., Folkerts-Landau, D. \& Garber, P. (2003). An essay on the revived Bretton Woods system. (NBER Working Paper No. 9971). Retrieved from NBER website. https://www.nber.org/papers/w9971.pdf

Eichengreen, B. (2017). Is Germany unbalanced or unhinged? Retrieved from https://www.project-syndicate.org/ commentary/german-external-surplus-requires-public-investment-by-barry-eichengreen-2017-05.

Engel, C., \& Rogers, J. (2006). The U.S. current account deficit and the expected share of world output. Journal of Monetary Economics, 53, 1063-1093. https://doi.org/10.1016/j.jmoneco.2006.05.002

Erceg, C. J., Guerrieri, L., \& Gust, C. (2005). Expansionary fiscal shocks and the trade deficit. International Finance Discussion Paper 825, Federal Reserve Board. https://www.federalreserve.gov/pubs/ifdp/2005/825/ifdp825.pdf

Falk, M. (2008). Determinants of the trade balance in industrialized countries. FIW Research Report, No. 013. https:// www.econstor.eu/handle/10419/121195

Feldstein, M. (2008). Resolving the global imbalance: The dollar and the U.S. saving rate. Journal Economic Perspectives, 22(3), 113-125. https://doi.org/10.1257/jep.22.3.113

Ferguson, R. W. (2004). “Global imbalances”, speech at European Institute Roundtable on Financial and Monetary Affairs. Washington, DC.

Ferrero, A. (2010). A structural decomposition of the U.S. trade balance: Productivity, demographics and fiscal policy. Journal of Monetary Economics, 57(4), 478-490.

Fox, A. J. (1972). Outliers in time series. Journal of the Royal Statistical Society B, 34, 350-363.

Fratzscher, M. (2017). Germany's misunderstood trade surplus. Retrieved from https://www.project-syndicate.org/ commentary/germany-trade-surplus-by-marcel-fratzscher-2017-03?barrier=accessreg.

Gantman, E. R., \& Dabós, M. P. (2017). Does trade openness influence the real effective exchange rate? New evidence from panel time-series. Series: Journal of the Spanish Economic Association, 9(1), 91-113. https://doi.org/10.1007/ s13209-017-0168-7

Ghosh, A., Qureshi, M., \& Tsangarides, C. (2013). Is the exchange rate regime really irrelevant for external adjustment? Economics Letters, 118(1), 104-109. https://doi.org/10.1016/j.econlet.2012.09.010

Ghosh, A., Qureshi, M., \& Tsangarides, C. (2014). The cost of tying one's hands. Finance \& Development, 51(2), 42-46.

Greenspan, A. (2005a). 'Current account', speech at Advancing Enterprise 2005 Conference, London, 4 February.

Greenspan, A. (2005b). 'Mortgage banking', speech at American Bankers Association Annual Convention, Palm Desert, California, 26 September.

Hansen, B. E. (2001). The new econometrics of structural change: Dating breaks in US labor productivity. Journal of Economic Perspectives, 15, 117-128. 
Hassan, M. S., Wajid, A., \& Kalim, R. (2017). Factors affecting trade deficit in Pakistan. India and Bangladesh. Economia Politca, 34(2), 283-304. https://doi.org/10.1007/s40888-017-0053-7

Himarios, D. (1989). Do devaluations improve the trade balance? The evidence revisited. Economic Inquiry, 27(1), 143-168. https://doi.org/10.1111/j.1465-7295.1989.tb01169.x

Hoffmann, M. (2013). What drives China's current account? Journal of International Money and Finance, 32, 856-883.

Hong, P. (2001). Global implications of the United States trade deficit adjustment. Discussion Paper of the United Nations Department of Economic and Social Affairs, No. 17, ST/ESA/2001/DP.17. https://www.un.org/esa/esa01 dp17.pdf

Hume, D. (1742). Essays, moral, political, and literary, of the balance of trade. Edinburgh, UK: R. Fleming and A. Alison, for A. Kincaid Bookseller.

Ibrahim, M. H. (2015). Oil and food prices in Malaysia: A nonlinear ARDL analysis. Agricultural Economics, 3(2), 3-14.

Ito, K. (2008). Global imbalances: Origins, consequences and possible resolutions. In J.-P. Touffout (Ed.), Central banks as economic institutions (pp. 142-161). Cheltenham, UK: Edward Elgar.

Kandil, M. (2009). On the relation between financial flows and the trade balance in developing countries. The Journal of International Trade \& Economic Development, 18, 373-393. https://doi.org/10.1080/09638190902986520

Kim, S., \& Roubini, N. (2008). Twin deficits or twin divergence? Fiscal policy, current account and real exchange rate in the U.S. Journal of International Economics, 74, 362-393.

Kollmann, R. (1998). US trade balance dynamics: The role of fiscal policy and productivity shocks and of financial market linkages. Journal of International Money and Finance, 4, 637. https://doi.org/10.1016/S0261-5606(98)00022-9

Laibson, D., \& Mollerstrom, J. (2010). Capital flows, consumption booms and asset bubbles: A behavioural alternative to the savings glut hypothesis. Economic Journal, 120(544), 354-374. https://doi.org/10.1111/j.1468-0297.2010.02363.x

Lee, J., \& Chinn, M. D. (1998). The current account and the real exchange rate: a structural VAR analysis of major currencies (NBER Working Paper No. 6495). Cambridge, MA: National Bureau of Economic Research. Retrieved from NBER website: https://www.nber.org/papers/w6495

Lee, J., \& Chinn, M. D. (2006). Current account and real exchange rate dynamics in the G7 countries. Journal of International Money and Finance, 25, 257-274. https://doi.org/10.1016/j.jimonfin.2005.11.002

Lee, J., McKibbin, W. J., \& Park, Y. C. (2006). Transpacific trade imbalances: Causes and cures. The World Economy, 29(3), 281-303.

Liew, K. S., Lim, K. P., \& Hussain, H. (2000). Exchange rate and trade balance: The experience of ASEAN countries. Journal of Management Sciences, 3, 15-18.

Loeffler, A. (2015). Reserve requirements and real exchange rate misalignments in emerging market economies. Review of Development Economics, 19(3), 516-530.

Mendoza, E., Quadrini, V., \& Rios-Rull, V. (2009). Financial integration, financial development and global imbalances. Journal of Political Economy, 117, 371-416. https://doi.org/10.1086/599706

Narayan, P. (2006). Examining the relationship between trade balance and exchange rate: The case of China's Trade with the USA. Applied Economics Letters, 13(8), 507-510. https://doi.org/10.1080/13504850500400488

Nasir, M. A., \& Jackson, K. (2019). An inquiry into exchanges rate misalignments as a cause of the major global trade imbalances. Journal of Economic Studies, 46(4), 902-924.

Nasir, M. A., \& Simpson, J. (2018). Brexit associated sharp depreciation and implications for UK's inflation and balance of payments. Journal of Economic Studies, 45(2), 231-246.

Perron, P. (1989). The great crash, the oil price shock and the unit root hypothesis. Econometrica, 57, $1361-1401$.

Perron, P. (2006). Dealing with structural breaks. In T. C. Mills, \& K. Patterson (Eds.), Econometric theory (pp. $278-$ 352). Basingstoke, UK: Palgrave Macmillan.

Pesaran, M. H., \& Shin, Y. (1999). An autoregressive distributed lag modelling approach to cointegration analysis. In S. Storm (Ed.), Econometrics and economic theory in the 20th century: The Ragnar Frisch centennial symposium. Cambridge, UK: Cambridge University Press. http://www.sciepub.com/reference/179240

Pesaran, M. H., Shin, Y., \& Smith, R. J. (2001). Bounds testing approaches to the analysis of level relationship. Journal of Applied Econometrics, 16, 289-326.

Ranganathan, T. \& Ananthakumar, U. (2010). Unit root test: Give it a break. The 30th International Symposium on Forecasting. Medford, MA: International Institute of Forecasters.

Reinhart, C. (2017). The persistence of global imbalances. Retrieved from https://www.project-syndicate.org/comme ntary/unbalanced-america-external-deficit-by-carmen-reinhart-2017-08. 
Rose, A. K. (1991). The role of exchange rates in a popular model of international trade: Does the 'Marshall-Lerner' condition hold? Journal of International Economics, 30(3), 301-316. https://doi.org/10.1016/0022-1996(91)90024 - Z

Rose, A. K., \& Yellen, J. L. (1989). Is there a J-Curve? Journal of Monetary Economics, 24(1), 53-68.

Sachs, J. D. (2017). Will economic illiteracy trigger a trade war? Retrieved from https://www.project-syndicate.org/ commentary/trump-economic-illiteracy-trade-war-by-jeffrey-d-sachs-2017-04.

Saadaoui, J., Mazier, J., \& Aflouk, N. (2013). On the determinants of exchange rate misalignments. Applied Economics Letters, 20(18), 1608-1610.

Shahbaz, M., Jalil, A., \& Islam, F. (2012). Real exchange rate changes and the trade balance: The evidence from Pakistan. The International Trade Journal, 26(2), 139-153. https://doi.org/10.1080/08853908.2012.657588

Shelburne, R. C. (2010). The global financial crisis and Its impact on trade: The world and the European emerging economies. Geneva, Switzerland: United Nations Economics Commission for Europe. Discussion Paper Series, No. 2010.2. https://www.unece.org/fileadmin/DAM/oes/disc_papers/ECE_DP_2010-2.pdf

Shin, Y., Yu, B., \& Greenwood-Nimmo, M. (2014). Modelling asymmetric cointegration and dynamic multiplier in a nonlinear ARDL framework. In W. Horrace \& R. Sickles (Eds.), The festschrift in honor of Peter Schmidt: Econometric methods and applications (pp. 281-314). New York, NY: Springer.

Sinn, H. W. (2014). The euro trap: On bursting bubbles, budgets, and beliefs, Oxford, UK: Oxford University Press.

Sinn, H.-W. (2017). President trump's necessary German lessons. Retrieved from https://www.project-syndicate.org/ commentary/trump-germany-currency-manipulation-charge-by-hans-werner-sinn-2017-03?barrier=accessreg.

Steinberg, J. B. (2018). On the source of U.S. trade deficits: Global saving glut or domestic saving drought? Review of Economic Dynamics, 31, 200-223.

Steiner, A. (2014). Current account balance and dollar standard: Exploring the linkages. Journal of International Money and Finance, 41, 65-94.

Stockman, A. C. (1985). Effects of inflation on the pattern of international trade. Canadian Journal of Economics, XVIII, 587-601.

Stucka, T. (2004). The effects of exchange rate change on the trade balance in Croatia (IMF Working Papers, no. 65). Retrieved from IMF website: https://www.elibrary.imf.org/view/IMF001/06922-9781451848717/06922-97814 51848717/06922-9781451848717.xml

Trade Facilitation and Enforcement Act (2015). Trade facilitation and enforcement act 20. Retrieved form www.congr ess.gov/114/plaws/publ125/PLAW-114publ125.pdf15

Tsay, R. S. (1988). Outliers, level shifts and variance changes in time series. Journal of Forecasting, 7(1), 1-20.

Variar, A. B. (2011). "Whose currency it is anyway?". Bricsforum.com, 1(47), 1-3.

Vogelsang, J. T. (1993). Essays on testing for nonstationarities and structural change in time series models. Unpublished Ph.D. Dissertation, Princeton, NJ: Princeton University.

Vogelsang, T. J., \& Perron, P. (1998). Additional tests for a unit root allowing for a break in the trend function at an unknown time. International Economic Review, 39(4), 1073-1100.

Wang, C.-H., Lin, C.-H.-A., \& Yang, C.-H. (2012). Short-run and long-run effects of exchange rate change on trade balance: Evidence from China and its trading partners. Japan and the World Economy, 24(4), $266-273$.

Yiheyis, Z., \& Musila, J. (2018). The dynamics of inflation, exchange rates and the trade balance in a small economy: The case of Uganda. International Journal of Development Issues, 17(2), 246-264. https://doi.org/10.1108/ IJDI-12-2017-0209

Yildirim, Z., \& Ivrendi, M. (2016). Exchange rate fluctuations and macroeconomic performance evidence from four fast-growing emerging economies. Journal of Economic Studies, 43(5), 678-698.

Yue, L. H., Qiang, J., \& Kai, T. Y. (2016). Determination of renminbi equilibrium exchange rate, misalignment, and official intervention. Emerging Markets Finance \& Trade, 52(2), 420-433.

Zhang, Z., \& Sato, K. (2012). Should Chinese Renminbi be blamed for its trade surplus? A structural VAR approach. The World Economy, 35, 632-650. https://doi.org/10.1111/j.1467-9701.2012.01438.x

Zivot, E., \& Andrews, K. (1992). Further evidence on the great crash, the oil price shock, and the unit root hypothesis. Journal of Business and Economic Statistics, 10(10), 251-270. 
How to cite this article: Nasir MA, Leung M. US trade deficit, a reality check: New evidence incorporating asymmetric and non-linear effects of exchange rate dynamics. World Econ. 2020;00:1-19. https://doi.org/10.1111/twec.12986

\section{APPENDIX}

\begin{tabular}{|c|c|}
\hline Variables & Definitions and sources \\
\hline Trade balance & $\begin{array}{l}\text { We used the current account balance as a percentage of GDP to represent } \\
\text { the trade balance of the United States. The data were extracted from the } \\
\text { Federal Reserve Bank of St. Louis }\end{array}$ \\
\hline Real effective exchange rate & $\begin{array}{l}\text { To present the exchange rate, we used the real effective exchange rate } \\
\text { as a proxy. The data were obtained from the Bank for the International } \\
\text { Settlement (BIS). We employed the board measure of the real effective } \\
\text { exchange rate }\end{array}$ \\
\hline Domestic inflation & $\begin{array}{l}\text { For the domestic inflation, we employed the data on GDP implicit price } \\
\text { deflator. It accounts for the changes in the price levels of domestically } \\
\text { produced goods and services and hence a better and most suitable measure } \\
\text { to gauge the price competitiveness of the domestically produced goods } \\
\text { and services. The source of data is the U.S. Bureau of Economic Analysis, } \\
\text { and the data are extracted from the Federal Reserve Bank of St. Louis }\end{array}$ \\
\hline Fiscal stance & $\begin{array}{l}\text { To present the fiscal outlook, we employed the data on the federal surplus/ } \\
\text { deficit as per cent of GDP. The source of data is Federal Reserve Bank of } \\
\text { St. Louis and U.S. Office of Management and Budget }\end{array}$ \\
\hline Savings & $\begin{array}{l}\text { For savings, we used the data on the personal saving ratios as a percentage } \\
\text { of disposable personal income. The data were seasonally adjusted and } \\
\text { obtained from the U.S. Bureau of economic analysis }\end{array}$ \\
\hline Productivity & $\begin{array}{l}\text { To represent the productivity, we employed the data on labour productivity } \\
\text { that refers to per hour output of all the workers engaged in the production. } \\
\text { The data were obtained from the Organisation for Economic Co-operation } \\
\text { and Development's (OECD) database }\end{array}$ \\
\hline
\end{tabular}

